\title{
EFEK SAFETY TALK TERHADAP PERILAKU K3 DI PROYEK APARTEMEN GRAND DHARMAHUSADA LAGOON SURABAYA
}

\author{
Romy Ananda Muslim ${ }^{1)}$ dan Feri Harianto') \\ 1) Jurusan Teknik Sipil, Institut Teknologi Adhi Tama Surabaya, Jawa Timur \\ romyananda17@gmail.com, feriharianto69@gmail.com
}

\begin{abstract}
The implementation of construction projects has a high risk of work accidents, one of the causes is the low level of awareness and understanding of workers about Occupational Health and Safety (OHS). One way to increase awareness and understanding of OHS is through safety talk activities. The purpose of this study was to determine the differences in OHS behavior between workers who followed and did not follow the safety talk. This research method used experiment design with safety talk treatment. Measurement of OHS behavior using a questionnaire with workers as respondents, a sample size of 15 people in each experimental group. The analysis used is the difference test with independent t-test analysis. The results showed a significant difference between workers who followed and did not participate in the safety talk with a value of $0.00<0.05$. Workers who take safety talk have better OHS behavior than workers who don't.
\end{abstract}

Keywords: difference test, OHS behavior, safety talk

\begin{abstract}
ABSTRAK
Pelaksanaan proyek konstruksi berisiko tinggi terjadinya kecelakaan kerja, salah satu penyebabnya adalah rendahnya kesadaran dan pemahaman tenaga kerja tentang keselamatan dan kesehatan kerja (K3). Salah satu cara meningkatkan kesadaran dan pemahaman K3 yaitu melalui kegiatan safety talk. Tujuan dari penelitian ini adalah mengetahui adanya perbedaan perilaku K3 antara pekerja yang mengikuti dan tidak mengikuti safety talk. Metode penelitian ini menggunakan experiment design dengan perlakuan safety talk. Pengukuran perilaku K3 menggunakan kuesioner dengan pekerja sebagai respondennya, ukuran sampel sebesar 15 orang ditiap kelompok experiment. Analisis yang digunakan adalah uji perbedaan dengan analisis uji independent t test. Hasil penelitian menunjukkan adanya perbedaan yang signifikan antara pekerja yang mengikuti dan tidak mengikuti safety talk dengan nilai $0.00<0.05$. Pekerja yang mengikuti safety talk memiliki perilaku K3 lebih baik dibandingkan dengan pekerja yang tidak mengikuti safety talk.
\end{abstract}

Kata kunci: uji perbedaan, perilaku K3, safety talk 


\section{PENDAHULUAN}

Kecelakaan kerja adalah kejadian yang jelas tidak dikehendaki dan sering kali tidak terduga yang dapat menimbulkan kerugian (Tarwaka, 2014). Salah satu penyebab kecelakaan kerja adalah masih rendahnya kesadaran dan pemahaman tentang keselamatan dan kesehatan kerja (K3). Hasil statistik menyatakan bahwa 85\% kecelakaan kerja disebabkan oleh faktor manusia dengan tindakan tidak aman (Ramli, 2010). Hal tersebut menjadikan faktor manusia yaitu perilaku K3 yang buruk menjadi penyumbang terbesar kecelakaan kerja. Salah satu upaya peningkatan aspek K3 adalah safety promotion yang salah satunya berbentuk kegiatan safety talk. Safety talk merupakan salah satu cara mengingatkan pekerja tentang betapa pentingnya aspek $\mathrm{K} 3$ dalam keberlangsungan operasional pekerjaan.

Kegiatan safety talk merupakan kegiatan pertemuan rutin yang dilakukan antara karyawan atau pekerja dan supervisor untuk membicarakan hal-hal K3, baik arahan keselamatan maupun membahas perkembangan K3 terbaru. Namun pada praktiknya meskipun safety talk merupakan kegiatan rutin yang wajib diikuti oleh para pekerja, masih banyak pekerja yang tidak mengikuti kegiatan tersebut dengan berbagai alasan. Hal ini menunjukkan bahwa rendahnya kesadaran keselamatan dan kesehatan kerja. Pada penelitian (Kurniawan, Setyaningsih, \& Wahyuni, 2017) menunjukkan bahwa meskipun kegiatan safety talk sudah berjalan dengan baik menurut para pekerjanya, akan tetapi keberlangsungan kegiatan safety talk yang baik tidak menunjukkan hubungan yang berarti dengan kepatuhan para pekerja. Sebaliknya, pada penelitian (Anggia, 2011) menunjukkan program safety talk yang dilakukan sebelum bekerja sangat efektif dalam memenuhi kebutuhan para karyawan akan informasi mengenai K3 dan membangun kesadaran para karyawan untuk lebih mengutamakan keselamatan kerja untuk mencegah timbulnya kecelakaan kerja. Hal ini pentingnya penelitian perilaku keselamatan kerja yang dikaitkan dengan kegiatan safety talk di proyek konstruksi. Tujuan penelitian ini adalah untuk mengetahui perbedaan perilaku K3 pekerja yang mengikuti dan tidak mengikuti safety talk.

\section{KAJIAN PUSTAKA}

\subsection{Safety Talk}

Safety talk atau juga sering disebut safety morning talk merupakan salah satu cara meningkatkan pengetahuan pekerja tentang pentingnya aspek $\mathrm{K} 3$ dalam berlangsungnya operasional pekerjaan 
untuk mencegah timbulnya kecelakaan kerja. Kegiatan ini diadakan rutin seminggu sekali dan diikuti oleh karyawan dan para pekerja, dengan isi kegiatan berupa arahan keselamatan dalam bekerja, pelatihan penggunaan alat tanggap darurat, dan materi-materi yang meningkatkan pengetahuan para pekerja tentang $\mathrm{K} 3$. Kegiatan safety talk diharapkan dapat meningkatkan wawasan dan perilaku K3 para pekerja agar meminimalisir kecelakaan kerja. Seperti yang diungkapkan (Kurniawan et al., 2017), bahwa safety talk merupakan salah satu penunjang dalam upaya mencegah terjadinya bahaya di tempat kerja.

\subsection{Perilaku}

Notoatmodjo (2011) menjelaskan bahwa perilaku merupakan suatu kegiatan atau aktivitasdari manusia itu sendiri, baik yang diamati secara langsung maupun yang tidak langsung. Perilaku manusia di pengaruhi oleh lingkungannya, baik lingkungan fisik maupun lingkungan budaya, latar belakang sosial, struktur sosial dan ekonomi. Robert Kwick (1974) dalam kutipan Notoatmodjo (2011) menyimpulkan bahwa perilaku berbeda dengan sikap. Perilaku adalah tindakan atau perbuatan suatu organisme yang dapat diamati dan dipelajari, sedangkan sikap merupakan kecenderungan untuk mengambil tindakan terhadap suatu objek dengan menyatakan menyenangi atau tidak menyenangi objek tersebut.

\section{METODE PENELITIAN}

Penelitian ini menggunakan metode desain eksperimen, dengan perlakuan safety talk. Variabel yang diukur adalah perilaku keselamatan kerja. Responden penelitian ini adalah mandor, tukang, dan pekerja. Penelitian dilakukan di lokasi Proyek Pembangunan Apartemen Grand Dharmahusada Lagoon Surabaya.

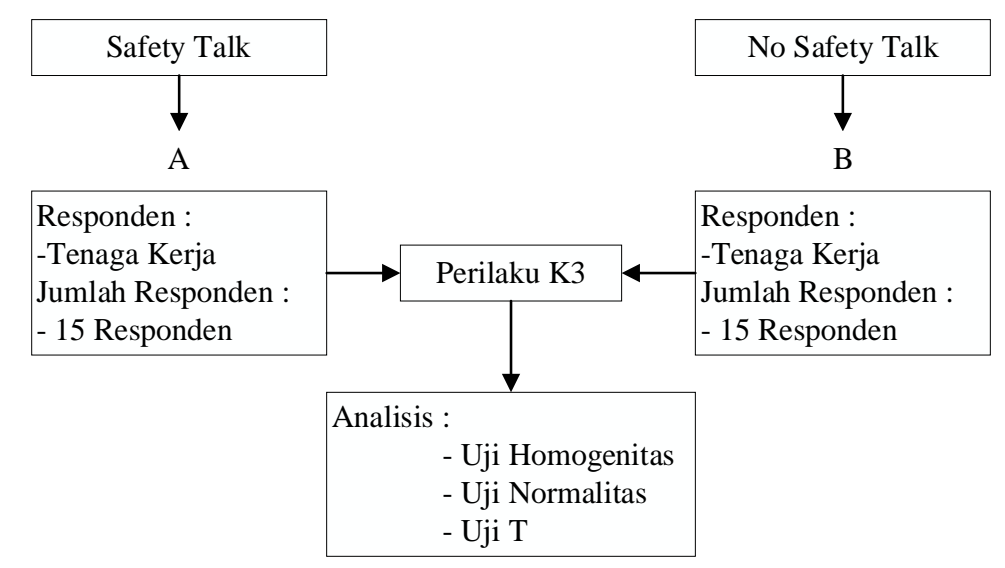

Gambar 1. Desain Penelitian 
Pada Gambar 1 terdapat dua kelompok sampel yaitu kelompok pekerja yang mengikuti safety talk dan kelompok pekerja yang tidak mengikuti safety talk. Teknik pengambilan sampel mengggunakan cluster sampling. Kelompok sampel yang mengikuti safety talk diambil dari pekerja tenaga besi, pengecoran, mekanikal dan elektrikal. Ukuran sampel tiap membutuhkan 15 responden (Wijaya, 2013). Instrumen untuk mengukur perilaku keselamatan digunakan kuesioner. Analisis data menggunakan uji homogenitas, uji normalitas, uji $\mathrm{t}$ dan interaksi faktorial dengan bantuan software SPSS.

\section{HASIL DAN PEMBAHASAN}

\subsection{Profil Data Responden}

Profil data responden dalam penelitian ini ditinjau berdasarkan usia, pendidikan dan pengalaman kerja.

Berdasarkan Tabel 1 sebagian besar usia responden yang mengikuti safety talk pada rentang usia 17-30 tahun dan diatas 44 tahun dengan prosentase $40 \%$ dan sebagian besar usia responden yang tidak mengikuti safety talk pada usia diatas 44 tahun dengan prosentase $47 \%$. Hasil penelitian (Harianto \& Widiyanto, 2013) menunjukkan bahwa usia merupakan salah satu faktor yang mempengaruhi perbedaan tenaga kerja dalam sikap dan perilaku. Pada Tabel 2, responden pada pekerja yang mengikuti safety talk sebagian besar adalah lulusan SMP dengan prosentase $60 \%$ dan pada responden pekerja yang tidak mengikuti safety talk sebagian besar adalah lulusan SMA dengan prosentase $47 \%$. Pendidikan memiliki peranan penting untuk meningkatkan kesadaran untuk berperilaku K3 yang baik agar terhindar dari kecelakaan kerja, hal ini sesuai dengan hasil penelitian (Faris \& Harianto, 2014) bahwa pendidikan seseorang sangat penting diperhatikan untuk meningkatkan kesadaran akan arti pentingnya kesehatan dan keselamatan kerja. Pada Tabel 3, pengalaman kerja pada responden yang mengikuti safety talk didominasi oleh pekerja dengan pengalaman pada rentang 10-20 tahun dengan prosentase $53 \%$, sedangkan pada responden yang tidak mengikuti safety talk semua memiliki pengalaman kerja rentang 1-10 tahun dengan prosentase $100 \%$. Pengalaman memiliki peranan penting dalam kedewasaan berperilaku dalam bekerja. Hal ini sesuai hasil penelitian (Faris \& Harianto, 2014) bahwa kewaspadaan terhadap kecelakaan kerja bertambah baik sesuai dengan pertambahan masa kerja dan lama bekerja. 
Tabel 1. Profil Responden Berdasarkan Usia

\begin{tabular}{ccccc}
\hline & \multicolumn{2}{c}{ Total Responden } & \multicolumn{2}{c}{ Prosentase (\%) } \\
\cline { 2 - 5 } Usia (th) & $\begin{array}{c}\text { Mengikuti } \\
\text { Safety Talk }\end{array}$ & $\begin{array}{c}\text { Tidak } \\
\text { Mengikuti } \\
\text { Safety Talk }\end{array}$ & $\begin{array}{c}\text { Mengikuti } \\
\text { Safety Talk }\end{array}$ & $\begin{array}{c}\text { Tidak } \\
\text { Mengikuti } \\
\text { Safety Talk }\end{array}$ \\
\hline $17-30$ & 6 & 5 & $40 \%$ & $33 \%$ \\
$31-43$ & 3 & 3 & $20 \%$ & $20 \%$ \\
$>44$ & 6 & 7 & $40 \%$ & $47 \%$ \\
Total & 15 & 15 & $100 \%$ & $100 \%$ \\
\hline
\end{tabular}

Tabel 2. Profil Responden Berdasarkan Pendidikan

\begin{tabular}{ccccc}
\hline \multirow{2}{*}{ Pendidikan } & \multicolumn{2}{c}{ Total Responden } & \multicolumn{2}{c}{ Prosentase (\%) } \\
\cline { 2 - 5 } & $\begin{array}{c}\text { Mengikuti } \\
\text { Safety Talk }\end{array}$ & $\begin{array}{c}\text { Tidak } \\
\text { Mengikuti } \\
\text { Safety Talk }\end{array}$ & $\begin{array}{c}\text { Mengikuti } \\
\text { Safety Talk }\end{array}$ & $\begin{array}{c}\text { Tidak } \\
\text { Mengikuti } \\
\text { Safety Talk }\end{array}$ \\
\hline SD & 4 & 6 & $27 \%$ & $40 \%$ \\
SMP & 9 & 2 & $60 \%$ & $13 \%$ \\
SMA & 2 & 7 & $13 \%$ & $47 \%$ \\
Total & 15 & 15 & $100 \%$ & $100 \%$ \\
\hline
\end{tabular}

Tabel 3. Profil Responden Berdasarkan Pengalaman Kerja

\begin{tabular}{|c|c|c|c|c|}
\hline \multirow[b]{2}{*}{$\begin{array}{c}\text { Pengalaman } \\
\text { Kerja (th) }\end{array}$} & \multicolumn{2}{|c|}{ Total Responden } & \multicolumn{2}{|c|}{ Prosentase $(\%)$} \\
\hline & $\begin{array}{l}\text { Mengikuti } \\
\text { Safety Talk }\end{array}$ & $\begin{array}{c}\text { Tidak } \\
\text { Mengikuti } \\
\text { Safety Talk }\end{array}$ & $\begin{array}{l}\text { Mengikuti } \\
\text { Safety Talk }\end{array}$ & $\begin{array}{c}\text { Tidak } \\
\text { Mengikuti } \\
\text { Safety } \\
\text { Talk }\end{array}$ \\
\hline $1-10$ & 4 & 15 & $27 \%$ & $100 \%$ \\
\hline $10-20$ & 8 & 0 & $53 \%$ & $0 \%$ \\
\hline$>20$ & 3 & 0 & $20 \%$ & $0 \%$ \\
\hline Total & 15 & 15 & $100 \%$ & $100 \%$ \\
\hline
\end{tabular}

\subsection{Uji Homogenitas.}

Hasil uji homogenitas yang diperoleh pada penelitian ini mendapatkan nilai signifikasi sebesar $0.771>0.05$, sehingga dapat disimpulkan bahwa varian data kuesioner responden yang mengikuti dan tidak mengikuti safety talk adalah sama atau homogen.

\subsection{Uji Normalitas.}

Dalam uji normalitas metode yang dipakai adalah uji Kolmogorov Smirnov. Hasil uji normalitas pada penelitian ini 
mendapatkan hasil nilai signifikasi (Sig.) dengan uji Kolmogorov Smirnov adalah sebesar $0.139>0.05$ pada responden yang mengikuti safety talk dan sebesar $0.057>$ 0.05 pada responden yang tidak mengikuti safety talk, sehingga dapat disimpulkan bahwa data penelitian berdistribusi normal pada lokasi populasi yang ditinjau.

\subsection{Uji T.}

Berdasarkan tabel 4, hasil uji independent sample $t$ test menunjukkan bahwa nilai signifikasi didapat nilai sebesar $0.00<0.05$, maka dapat dinyatakan bahwa terdapat perbedaan signifikan hasil perilaku $\mathrm{K} 3$ antara responden yang mengikuti dan tidak mengikuti safety talk.

Tabel 4. Uji Independent Sample T Test

\begin{tabular}{cccccc}
\hline No & Responden & Variabel & $\begin{array}{c}\text { Nilai Signifikasi Uji } \\
\text { Independent Sample T } \\
\text { Test }\end{array}$ & $\begin{array}{c}\text { Standar } \\
\text { Keputusan }\end{array}$ & Keterangan \\
\hline Mengikuti Safety & Perilaku & 0.00 & 0.05 & $\begin{array}{c}\text { Perbedaan } \\
\text { Signifikan }\end{array}$ \\
\hline & $\begin{array}{c}\text { Talk dan Tidak } \\
\text { Mengikuti Safety } \\
\text { Talk }\end{array}$ & K3 & & & \\
\hline
\end{tabular}

\subsection{Rerata Perilaku K3}

Pada Tabel 5, nilai rerata 67.00 untuk responden pekerja yang mengikuti safety talk, sementara untuk responden yang tidak mengikuti safety talk memiliki nilai rerata 50.47. Hasil tersebut sejalan dengan penelitian (Anggia, 2011), yang menunjukkan program safety talk yang dilakukan sebelum bekerja sangat efektif dalam memenuhi kebutuhan para karyawan akan informasi mengenai K3 dan membangun kesadaran para karyawan untuk lebih mengutamakan keselamatan kerja untuk mencegah timbulnya kecelakaan kerja.

Tabel 5. Nilai Rerata Perilaku K3

\begin{tabular}{llcccc}
\hline \multicolumn{5}{c}{ Group Statistics } \\
\hline Responden & & N & Mean & Std. Deviation & Std. Error Mean \\
\hline & Mengikuti Safety Talk & 15 & 67.00 & 11.656 & 3.010 \\
Perilaku K3 & $\begin{array}{l}\text { Tidak Mengikuti Safety } \\
\text { Talk }\end{array}$ & 15 & 50.47 & 11.186 & 2.888 \\
\hline
\end{tabular}


Tabel 6. Nilai Rerata Perilaku K3 Berdasarkan Jabatan Kerja

\begin{tabular}{ccc}
\hline Responden & Jabatan & Nilai Rata-Rata Kuesioner \\
\hline \multirow{2}{*}{ Mengikuti Safety } & Mandor & 57.00 \\
Talk & Tukang & 69.00 \\
& Pekerja Kasar & 66.00 \\
Tidak Mengikuti & Mandor & 49.50 \\
Safety Talk & Tukang & 50.29 \\
& Pekerja Kasar & 51.00 \\
\hline
\end{tabular}

Tabel 7. Nilai Rerata Perilaku K3 Berdasarkan Usia

\begin{tabular}{ccc}
\hline Responden & Usia & Rata-Rata Nilai Kuesioner \\
\hline Mengikuti Safety & 17 - 30 Tahun & 63.33 \\
Talk & 31 - 43 Tahun & 73.00 \\
& Diatas 44 Tahun & 64.67 \\
Tidak Mengikuti & 17 - 30 Tahun & 46.00 \\
Safety Talk & 31 - 43 Tahun & 49.33 \\
& Diatas 44 Tahun & 54.14 \\
\hline
\end{tabular}

Tabel 8. Nilai Rerata Perilaku K3 Berdasarkan Pendidikan

\begin{tabular}{ccc}
\hline Perlakuan & Pendidikan & Rata-Rata Nilai Kuesioner \\
\hline \multirow{2}{*}{ Mengikuti Safety } & SD & 68.50 \\
Talk & SMP & 65.11 \\
& SMA & 72.50 \\
Tidak Mengikuti & SD & 53.17 \\
Safety Talk & SMP & 49.00 \\
& SMA & 48.57 \\
\hline
\end{tabular}

Tabel 9. Nilai Rerata Perilaku K3 Berdasarkan Variabel Pengalaman Kerja

\begin{tabular}{ccc}
\hline Perlakuan & Pengalaman Kerja & Rata-Rata Nilai Kuesioner \\
\hline Mengikuti Safety & 1 - 10 Tahun & 67.50 \\
Talk & 10 - 20 Tahun & 69.71 \\
& $>$ 20 Tahun & 61.75 \\
Tidak Mengikuti & 1 - 10 Tahun & 50.47 \\
Safety Talk & 10 - 20 Tahun & - \\
\hline
\end{tabular}


Berdasarkan Tabel 6, jabatan mandor baik pada responden yang mengikuti maupun yang tidak mengikuti safety talk memiliki nilai hasil rata-rata paling rendah diantara jabatan kerja lainnya dengan nilai 57.00 pada mandor yang mengikuti safety talk dan nilai 49.50 pada mandor yang tidak mengikuti safety talk. Meskipun jabatan mandor memiliki perilaku K3 yang rendah, tetapi mereka memiliki tenaga kerja yang di bawahinya yang memiliki nilai perilaku K3 yang baik ditunjukkan dengan pekerja yang mengikuti safety talk nilai rata-rata tertinggi didapat pada jabatan tukang dengan nilai 69.00 dan pada pekerja yang tidak mengikuti safety talk nilai rata-rata tertinggi pada jabatan pekerja kasar dengan nilai 51.00. Hasil tersebut menunjukkan bahwa seorang mandor harus dapat memberi pengaruh terhadap tenaganya untuk bekerja dan berperilaku K3 yang baik. Sejalan dengan yang diungkapkan Musthofa (2015) bahwa seorang mandor tentu memiliki motivasi dan tanggung jawab yang menjadi nilai jual yang dimilikinya. Motivasi yang diberikan dapat diartikan daya psikis yang menggerakkan pekerja sehingga menimbulkan kegiatan bekerja untuk mencapai tujuan tertentu.

Berdasarkan Tabel 7, pekerja dengan rentang usia 17-30 tahun menjadi usia pekerja yang memiliki nilai rerata terendah baik pada responden yang mengikuti maupun tidak mengikuti safety talk dengan nilai 63.33 pada responden yang mengikuti safety talk dan nilai 46.00 pada responden yang tidak mengikuti safety talk. Sebaliknya nilai rata-rata tertinggi pada responden yang mengikuti safety talk didapat pekerja pada rentang usia 31-43 tahun dengan nilai 73.00 dan pada responden yang tidak mengikuti safety talk didapat pekerja pada usia diatas 44 tahun dengan nilai 54.14. Dari hasil tersebut menunjukkan usia berpengaruh terhadap perilaku K3, usia pekerja yang lebih tua memiliki perilaku yang lebih baik daripada pekerja dengan usia muda. Hal ini sejalan dengan penelitian (Apriluana, Khairiyati, \& Setyaningrum, 2016) bahwa usia muda merupakan fase dimana sedikit pemahaman tentang $\mathrm{K} 3$, semakin cukup usia seseorang memberikan tingkat kemampuan yang lebih matang dalam berpikir dan bekerja.

Ditinjau berdasarkan Tabel 8, nilai hasil statistik deskriptif variabel pendidikan menunjukkan pada responden pekerja yang mengikuti safety talk semakin tinggi pendidikan memberikan hasil perilaku K3 yang lebih baik, hal ini ditunjukkan dengan nilai rata-rata tertinggi di dapat pada responden dengan pendidikan SMA dengan nilai 72.50. Hal ini menunjukkan pendidikan sangatlah penting dalam 
meningkatkan kesadaran dalam berperilaku K3 pada pekerja yang mengikuti safety talk. Sejalan dengan hasil penelitian (Faris \& Harianto, 2014) bahwa pendidikan sangatlah penting dalam meningkatkan kesadaran dalam berperilaku $\mathrm{K} 3$. Sebaliknya pada responden yang tidak mengikuti safety talk nilai rata-rata tertinggi didapat pekerja dengan pendidikan SD dengan nilai 53.17. Pada responden pekerja yang tidak mengikuti safety talk semakin tinggi tingkat pendidikan menunjukkan semakin rendahnya perilaku K3. Hal ini menunjukkan bahwa latar belakang pendidikan tidak berpengaruh terhadap hasil perilaku K3 pada responden pekerja yang tidak mengikuti safety talk. Hal tersebut sesuai hasil penelitian (Aryanto, Ekawati, \& Kurniawan, 2016), bahwa latar belakang pendidikan tidak terlalu berpengaruh terhadap cara pikir pekerja untuk bekerja dengan aman.

Berdasarkan Tabel 9, menunjukkan bahwa bertambahnya pengalaman kerja berpengaruh terhadap nilai perilaku $\mathrm{K} 3$ pekerja. Hal tersebut ditunjukkan dengan nilai hasil statistik deskriptif variabel pengalaman kerja pada responden pekerja yang mengikuti safety talk nilai rata-rata tertinggi didapat pekerja dengan rentang pengalaman 10-20 tahun dan pada responden pekerja yang tidak mengikuti safety talk semua pekerja memiliki pengalaman pada rentang 1-10 tahun dengan nilai 50.47. Hal ini sesuai dengan hasil penelitian (Faris \& Harianto, 2014), bahwa bertambahnya pengalaman kerja lebih besar kemungkinan terhindar dari kecelakaan kerja.

\subsection{Interaksi Faktorial Antar Variabel Profil Data responden}

Analisis ini menampilkan distribusi data secara lebih jelas, sehingga akan memberikan gambaran bagaimana sebaran data hasil perilaku K3 pekerja yang mengikuti safety talk jika terdapat interaksi antar variabel profil data responden, yaitu jabatan kerja, usia, pendidikan dan pengalaman kerja.

Pada Gambar 2, pengaruh jabatan kerja dan usia terhadap perilaku K3 dengan perlakuan safety talk menunjukkan perilaku tertinggi pada jabatan tukang dengan usia 31-43 tahun. Usia 31-43 adalah usia produktif dimana dianggap matang dalam cara berpikir dan mengambil keputusan seperti yang diungkapkan (Gunawan \& Mudayana, 2016). Pada jabatan tenaga kasar semakin tua umur pekerja memberikan peningkatan hasil perilaku K3 yang lebih baik. Sejalan yang diungkapkan (Shiddiq, Wahyu, \& Muis, 2013), bahwa faktor umur mempengaruhi logika berfikir dan pengetahuan sehingga semakin matang 
usia semakin bertambah kedewasaan, menunjukkan penurunan perilaku K3 pada kecerdasannya dan kemampuan umur semakin tua. Menurut (Shiddiq et al., mengendalikan emosi yang dapat 2013), bertambahnya umur belum tentu mengurangi terjadinya kecelakaan kerja. diiringi bertambahnya kedewasaan Sebaliknya pada jabatan tukang pola grafik seseorang dalam berperilaku.

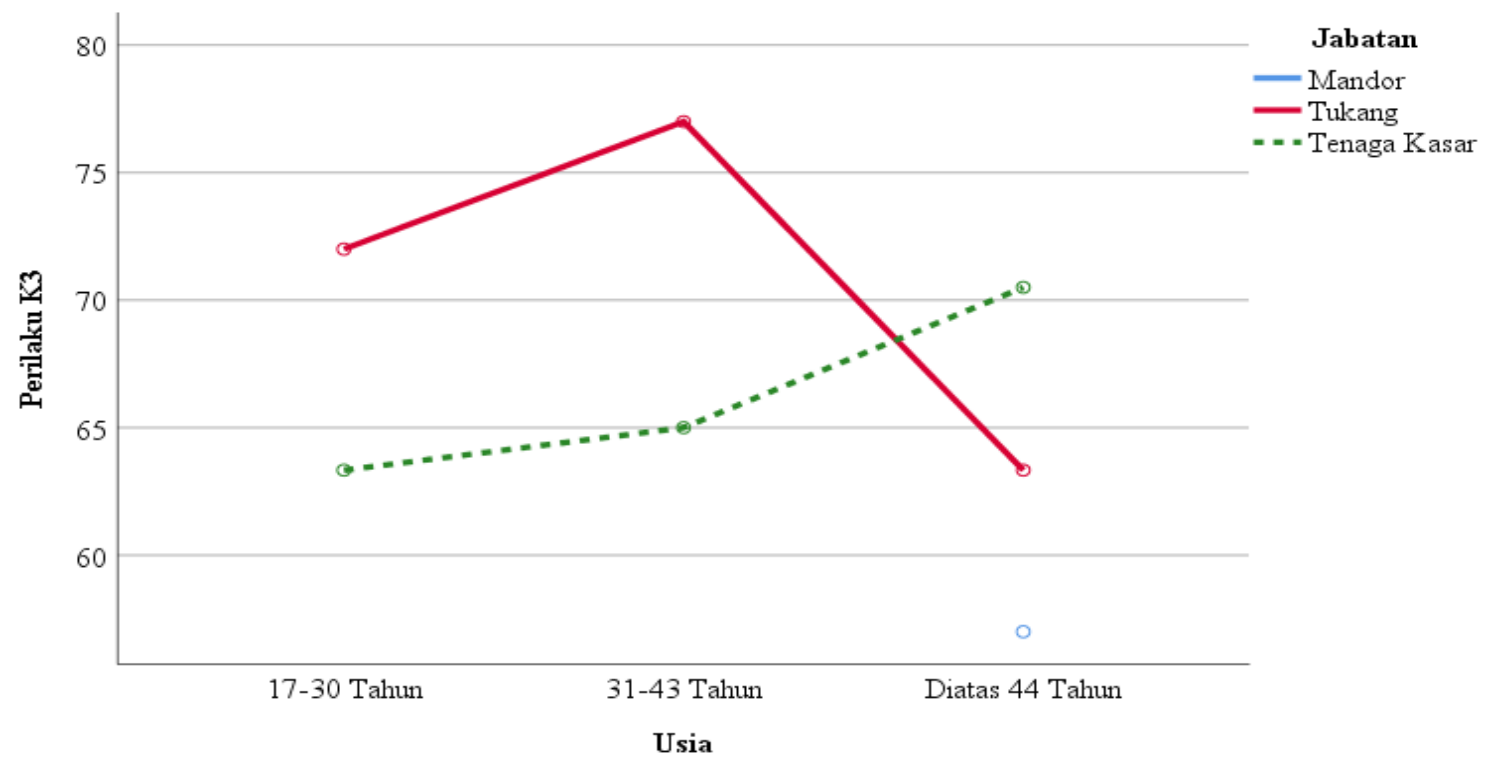

Gambar 2. Pengaruh Jabatan Kerja dan Usia Terhadap Perilaku K3 Dengan Perlakuan
Safety Talk

Pada Gambar 3, Pengaruh jabatan kerja dan pendidikan terhadap perilaku K3 dengan perlakuan safety talk menunjukkan perilaku tertinggi didapat oleh jabatan tukang dengan pendidikan SMA. Menurut (Gunawan \& Mudayana, 2016), pendidikan SMA adalah tingkat pendidikan kategori menengah dimana sudah baik dalam bekerja. Bila dilihat dari pola grafik, pada jabatan tenaga kasar semakin baik tingkat pendidikan diikuti menurunnya kualitas perilaku K3. Menurut (Aryanto et al., 2016), bahwa pola berpikir untuk bekerja dengan aman tidak begitu dipengaruhi oleh latar belakang pendidikan, namun peningkatan pola pikir bekerja aman dapat ditingkatkan dengan memberikan pelatihan. Pada jabatan tukang pola grafik menunjukkan semakin tinggi tingkat pendidikan diikuti dengan semakin baiknya perilaku K3. Menurut (Endriastuty \& Adawia, 2018) pendidikan yang baik akan mencerminkan pengetahuan dan keterampilan sebagai prediktor kerja seseorang. 


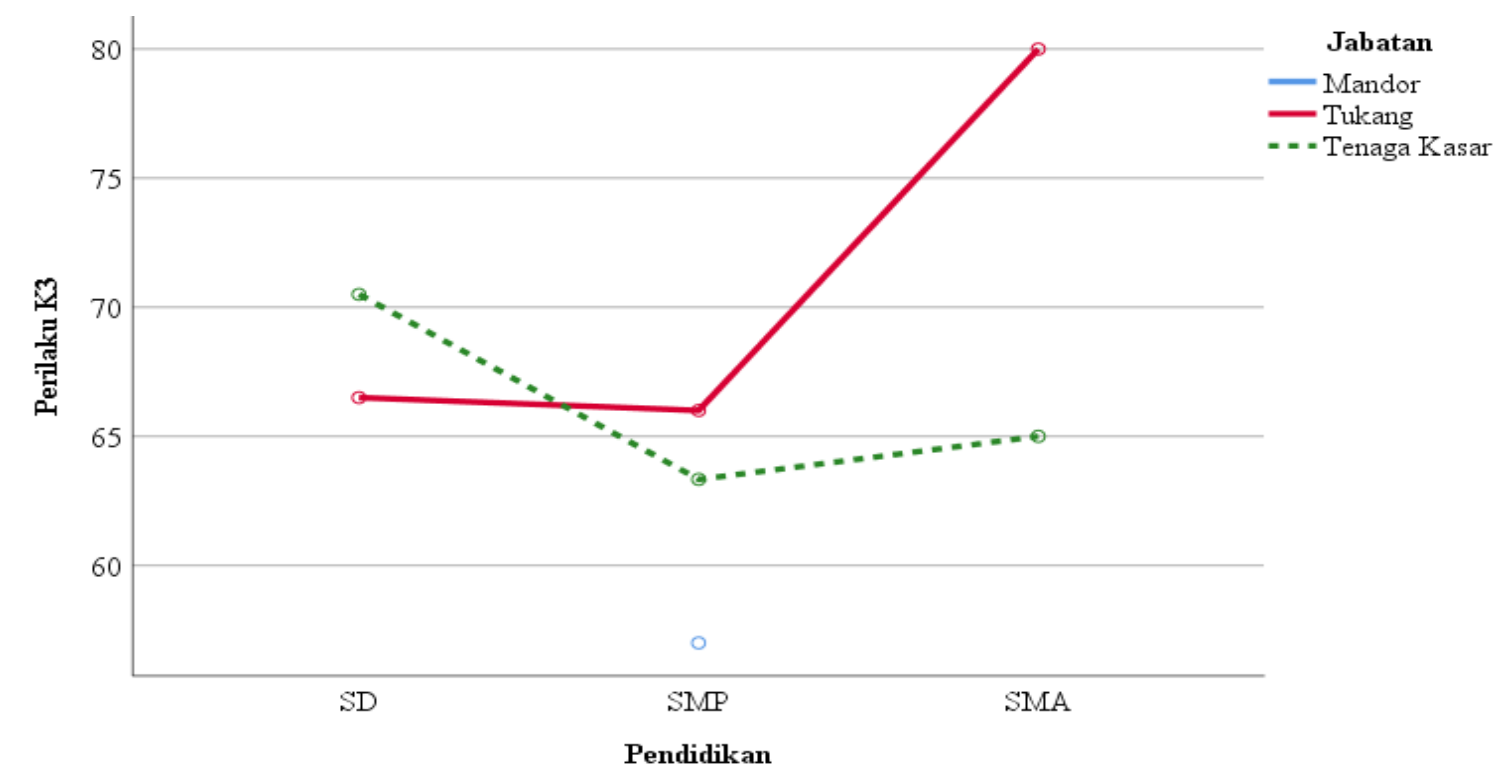

Gambar 3. Pengaruh Jabatan Kerja dan PendidikanTerhadap Perilaku K3 Dengan Perlakuan Safety Talk

Pada Gambar 4, Pengaruh jabatan kerja dan pendidikan terhadap perilaku K3 dengan perlakuan safety talk menunjukkan perilaku tertinggi didapat oleh jabatan tukang dengan pengalaman kerja 1-10 tahun dan jabatan tenaga kasar dengan pengalaman kerja lebih dari 20 tahun. Hasil tersebut menunjukkan bertambahnya pengalaman kerja berpengaruh meningkatkan perilaku K3. Sejalan dengan yang diungkapkan (Faris \& Harianto, 2014) bahwa bertambahnya pengalaman kerja lebih besar kemungkinan terhindar dari kecelakaan kerja. Setidaknya pekerja yang memiliki pengalaman kerja lebih mengetahui secara mendalam seluk beluk pekerjaan dan keselamatannya. Pada jabatan tenaga kasar semakin tinggi pengalaman kerja menunjukkan peningkatan perilaku K3. Sejalan hasil penelitiannya (Faris \& Harianto, 2014), bahwa pekerja dengan banyak pengalaman memiliki perilaku K3 yang baik menimbulkan kewaspadaan terhadap kecelakaan kerja dan lebih mementingkan keselamatan dari pada cepat selesainya suatu pekerjaan. Sebaliknya pada jabatan tukang, pola grafik menunjukkan semakin tinggi pengalaman kerja diikuti menurunnya kualitas perilaku K3. Hal ini sesuai hasil penelitian (Apriluana et al., 2016) bahwa pengalaman berpengaruh terhadap pengetahuan seseorang, namun memiliki pengalaman yang lebih lama kadang membuat produktivitas menurun akibat timbulnya rasa bosan yang mempengaruhi perilaku K3. 


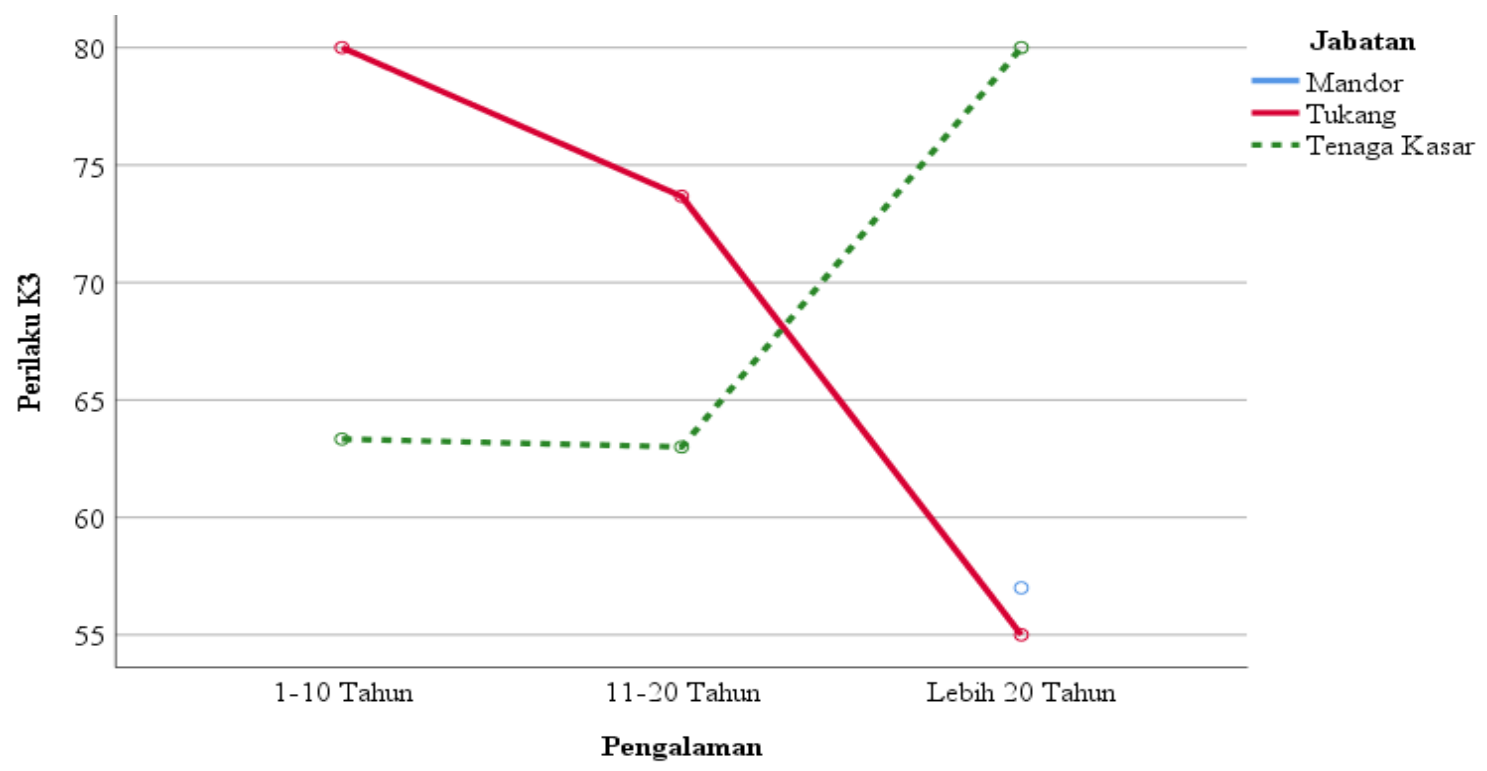

Gambar 4.Pengaruh Jabatan Kerja dan Pengalaman KerjaTerhadap Perilaku K3 Dengan Perlakuan Safety Talk

\section{SIMPULAN}

Terdapat perbedaan perilaku K3 antara pekerja yang mengikuti dan tidak mengikuti safety talk $(0.00<0.05)$. Pekerja yang mengikuti safety talk memiliki perilaku K3 lebih baik ditunjukkan dengan nilai rata-rata 67.00, dibandingkan pekerja yang tidak mengikuti safety talkdengan nilai rata-rata 50.47. Sehingga dapat disimpulkan safety talk efektif meningkatkan perilaku K3 pekerja.

\section{DAFTAR PUSTAKA}

Anggia, N. (2011). Efektivitas Komunikasi Safety Talk Sebagai Pemenuhan Informasi K3 Bagi Karyawan PT. Multikon. Rashid RA, dkk. 2014. Impact of Safety Communication on Safety Commtiment with LeaderMember Exchange Quality as A Moderating Factor: A Conceptual Frame Work.
Apriluana, G., Khairiyati, L., \& Setyaningrum, R. (2016). Hubungan Antara Usia, Jenis Kelamin, Lama Kerja, Pengetahuan, Sikap Dan Ketersediaan Alat Pelindung Diri (APD) Dengan Perilaku Penggunaan Apd Pada Tenaga Kesehatan. Jurnal Publikasi Kesehatan Masyarakat Indonesia.

Aryanto, L., Ekawati, E., \& Kurniawan, B. (2016). Hubungan Pelatihan, Status Kerja, Latar Belakang Pendidikan, dan Penggunaan Alat Pelindung Diri dengan Terjadinya Kecelakaan Kerja pada Total E\&P Indonesia. Jurnal Kesehatan Masyarakat Universitas Diponegoro.

Endriastuty, Y., \& Adawia, P. R. (2018). Analisa Hubungan Antara Tingkat Pendidikan, Pengetahuan Tentang K3 Terhadap Budaya K3 Pada Perusahaan Manufaktur. Jurnal Ecodemica: Jurnal Ekonomi, Manajemen, Dan Bisnis, 2(2).

Faris, I. Al, \& Harianto, F. (2014). Pengaruh Perilaku Tenaga Kerja Dan 
Lingkungan Kerja Yang Dimoderasi Faktor Pengalaman Kerja Dan Tingkat Pendidikan Terhadap Kecelakaan Kerja Konstruksi Di Surabaya. Jurnal Seminar Nasional X - 2014 Teknik Sipil ITS Surabaya.

Gunawan, I., \& Mudayana, A. A. (2016). Hubungan antara Pengetahuan, Sikap dan Motivasi dengan Perilaku Penggunaan Alat Pelindung Diri pada Pekerja Bagian Produksi PT. Katingan Indah Utama, Kabupaten Kotawaringin Timur, Provinsi Kalimantan Tengah. Unnes Journal of Public Health. https://doi.org/10.15294/ujph.v5i4.12 421

Harianto, F., \& Widiyanto, A. (2013). Ketahanan Tenaga Kerja Proyek Konstruksi dengan Menggunakan Survival Analysis. Seminar Nasional IX-2013 Teknik Sipil ITS Surabaya: Peran Industri Konstruksi Dalam Menunjang MP3EI (Masterplan Percepatan Dan Perluasan Pembangunan Ekonomi Indonesia),(I35-I-43).

Kurniawan, W., Setyaningsih, Y., \& Wahyuni, I. (2017). Hubungan Faktor Karakteristik Pekerja, Safety Morning Talk (SMT) dan Housekeeping dengan Kejadian Minor Injury Pada Pekerja di Proyek Pembangunan Gedung Kantor PT. X Jakarta. Jurnal Kesehatan Masyarakat Universitas Diponegoro.

Notoatmodjo, S. (2011). Kesehatan Masyarakat Ilmu \& Seni. In Rineka Cipta.

Ramli, S. (2010). Sistem Manajemen Keselamatan \& Kesehatan Kerja. Dian Rakyat, Jakarta.

Shiddiq, S., Wahyu, A., \& Muis, M. (2013). Hubungan Persepsi K3 Karyawan dengan Perilaku Tidak Aman di Bagian Produksi Unit IV PT. Semen
Tonasa Tahun 2013. None.

Tarwaka. (2014). Occupational Safety and Health, Management and implementation of Occupational Health and Safety at work. In Surakarta: Harapan Press.

Wijaya, T. (2013). Metodologi penelitian ekonomi dan bisnis teori dan praktik. Yogyakarta: Graha Ilmu. 